\title{
Potential of landfill biogas production for power generation in the Valencian region (Spain)
}

\author{
Carlos Vargas-Salgado $^{1}$, Jesús Águila-León ${ }^{2}$, Cristian Chiñas-Palacios ${ }^{2}$ Lina Montuori $^{3}$ \\ ${ }^{1}$ Department of electrical Engineering, Universitat Politecnica de Valencia, Spain, \\ ${ }^{2}$ University of Guadalajara, Mexico, ${ }^{3}$ Department of Applied Thermodynamics, Universitat \\ Politecnica de Valencia, Spain.
}

\begin{abstract}
Landfills are still one of the most common ways to dispose solid urban waste in many countries due to their relatively simple technical requirements, operational costs and low investment. Moreover, biogas produced in landfills can be used as a renewable energy source for power generation. The Valencian region is one of the largest solid urban waste producers in Spain, and therefore, it may have an unexplored potential of landfill biogas production. This paper aims to estimate the landfill biogas production and its power generation potential for the Valencian region to provide related information about the use of landfill gas as an alternative source of energy. Statistical data from urban solid waste in landfills were gathered from the provinces of Alicante, Castellon, and Valencia, then the assessment of landfill biogas production was estimated by means of waste classification and disposal for each province. Results presented in this work show that the Valencian region has an important potential to use landfill biogas from solid urban waste as a renewable source for power generation, and also provide insights in valuable information to the Spanish government, academic researches, policymakers, and possible investors.
\end{abstract}

Keywords: Solid urban waste management; landfill biogas; bioenergy potential; power generation; renewable energy; Valencian region. 


\section{Introduction}

A dump is a place where Urban Solid Waste (USW) is deposited. If there is no type of control in these dumps, the containing waste can cause foul smells, pollute nearby waters, be a focal point for rodents and insects, produce emissions of Greenhouse Gases (GHG) into the atmosphere and provoke fires due to the combustion of the combustible gas with high methane concentration resulting from the decomposition of the rubbish (Igliński, Buczkowski, \& Cichosz, 2015).

Landfills, on the other hand, are places to prevent pollution, help the environment and protect human's health. Trash deposited on landfills is covered to prevent odors and to stop trash from flying away. Biogas is obtained by trash decomposing. The landfill gas is collected in pipes and recycled into fuel and later it could produce electricity. Its main components are methane (40-70\% of $\mathrm{CH}_{4}$ ) and carbon dioxide (30-60\% of $\mathrm{CO}_{2}$ ) in addition to other gases (1$5 \%$ of $\mathrm{H}_{2}, \mathrm{~N}_{2}$ or $\mathrm{H}_{2} \mathrm{SO}_{4}$ ). The gas composition depends on weather conditions, landfill characteristics or waste composition and treatment (Nadaletti et al., 2015). It is also important to emphasize that methane is the second largest contributor to global warming among GHG, after carbon dioxide.

Biogas can be used to generate electricity by using an internal combustion engine coupled to an electric generator. Many worldwide studies have reported detailed information about the estimates of power potential from biogas in landfills sites in several countries, such as Brazil, Bolivia, Mexico, and Poland (Igliński et al., 2015; Lima et al., 2018; Rios \& Kaltschmitt, 2016; Vargas Bautista \& Calvimontes, 2017).

\subsection{Solid waste in the Valencian Region}

Waste management has increasingly become in one of the main society challenges nowadays, given its growing generation and great environmental, social and economic impact. According to the Institute for Diversification and Energy Savings (Instituto de Diversificación y Ahorro de Energía - IDAE), in Spain, each citizen approximately generates about $1,5 \mathrm{~kg}$ of SUW per day (Diversificación y Ahorro de Energía, Armengol, \& Farré, 2011). In the Valencian region, around 21 million tons of USW are generated every year (a ( $47 \%$ in Valencia, $41 \%$ in Alicante and 12\% in Castellón). The average generation per capita is about 1,2 kg of solid waste per day. (Infraestructuras Territorio y Medio Ambiente, 2012). Table 1 shows the annual solid waste generated in the Valencian region. 
Table 1. The annual solid waste generated in the Valencian region (2016 to 2019).

\begin{tabular}{cccc}
\multirow{2}{*}{ Year } & \multicolumn{3}{c}{ Amount of solid waste (tons) } \\
\cline { 2 - 4 } & Alicante & Castellon & Valencia \\
\hline 2016 & 1.099 .004 & 315.398 & 1.233 .681 \\
2017 & 1.098 .186 & 315.163 & 1.232 .762 \\
2018 & 1.097 .240 & 314.892 & 1.231 .701 \\
$2019 *$ & 1.096 .167 & 314.584 & 1.230 .496 \\
\hline \multicolumn{4}{l}{ Source: (Infraestructuras Territorio y Medio Ambiente, 2012). } \\
\end{tabular}

\subsubsection{Composition of the solid waste}

According to the conselleria de infraestructra fo Valencia Region, the main elements that make up the characterization of solid waste in the region of Valencia are $41 \%$ organic matter, $29 \%$ packaging and $30 \%$ other materials. The total of packaging composition is represented by $41 \%$ plastic, $22 \%$ paper, $19 \%$ glass, $13 \%$ metals and $5 \%$ cardboard. For the total composition of others: $42 \%$ paper \& cardboard, $9 \%$ plastic, $5 \%$ metals, $1 \%$ glass, $11 \%$ ground $\&$ ashes, $3 \%$ wood and $15 \%$ others. The average estimate of composition is shown in Figure 1.

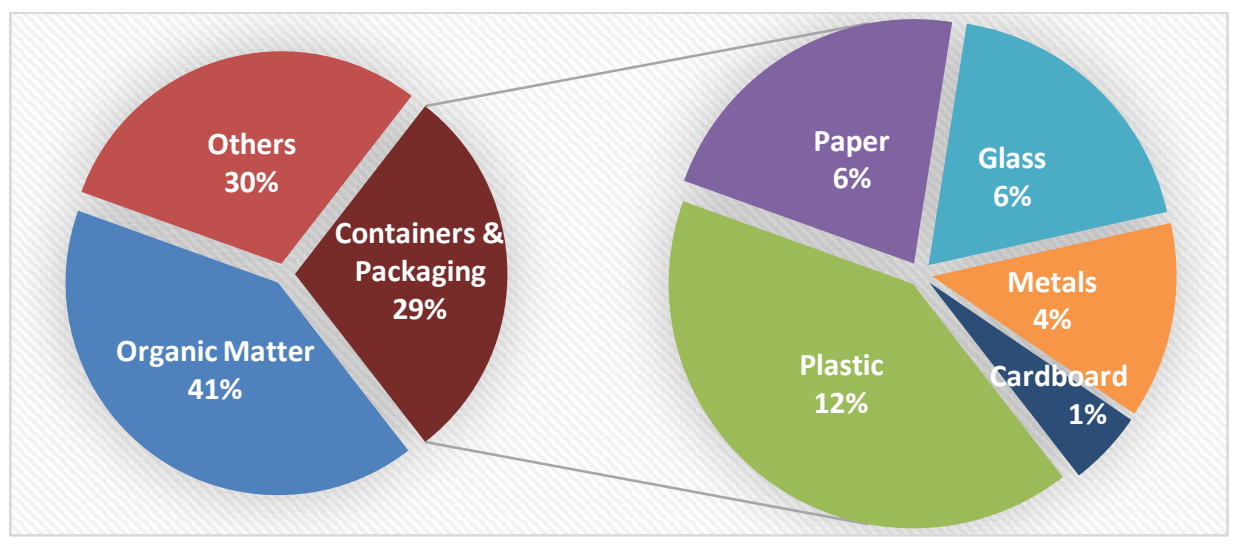

Figure 1 Average composition of the solid waste in the Valencian region. Source: (Consellería de Infraestructuras, 2013).

In this paper will be carried out the estimation of power generation from the biogas produced from the solid urban waste in the landfills of the provinces of Alicante, Castellon, and Valencia, and the reduction of emission of $\mathrm{CO}_{2}$. For such purpose, an economic model for the evaluation and feasibility of the project will be used. 


\section{Methodology}

Two models were applied to estimate the use of biogas for the Valencian region; the first estimates the production of biogas and the second estimates the generation of electricity from biogas. Data from 2012 to 2015 were used for a prediction over the year 2026. Once the predictions were produced, the results were tabulated and compared against the estimates of energy demand and USW production of the Valencian region. According to (Sanchís, 2019) currently in the Region of Valencia there are three main operating landfills; Onda in the province of Castellon, filled since 2014, Dos Aguas (in Phase 2), in the province of Valencia which has been active since 2010 and with a current lifespan of 5,6 years being at $51,7 \%$ of its capacity, and finally the Alicante landfill, active since 2005, with a last life of 4,75 years being at $82,3 \%$ of its capacity. For simplification purposes, this work raises the scenario that the production of biogas in the Valencian Region depends entirely on these three landfills and since their lifetime is about to be exhausted. It is supposed that before 2024 will be opened at least three landfills with equal capacity to the current ones to cover the needs of trash disposal. Such landfills also ensure an increment in the biogas production in the future.

\subsection{Prediction Model of Landfill Biogas}

The composition of biogas depends on: the characteristics and volume of the residue, moisture, compaction and age of the landfill. The generation of biogas emissions varies over time and with environmental conditions, so there are several models for estimating the generation of biogas in landfills. In this work the biogas generation potential per year was calculated using the Landfill Gas Emission Model (LandGEM) of the U.S. Environmental Protection Agency (EPA). LandGEM first-order degradation model has been implemented obtaining good results about landfill gas emission rate per year (Vargas Bautista \& Calvimontes, 2017). Its formula is shown in Eq. 1.

$$
Q=2 \sum_{i=1}^{n} k L_{0} M_{i} e^{-k t_{i}}
$$

Equation 1

Where $Q$ is the total landfill biogas emission rate per year $\left(m^{3} / y\right), n$ is the number of years of waste placement, $k$ is the landfill gas generation rate constant $\left(y^{-1}\right), M_{i}$ is the mass in mega grams of the solid waste section placed in year $i(M g), L_{0}$ is the methane generation potential $\left(\mathrm{m}^{3} / \mathrm{Mg}\right)$ and $t_{i}$ is the age of the waste section placed in year $i(y)$. The Equation 1 model was applied using USW data from the Valencian region from the years 2013 to 2016 as inputs.

\subsection{Prediction Model for Power Generation}

The process for power generation consists in extracting the biogas from the landfill through a series of pipes that transport it to a storage tank. Once the annual biogas production data is 
obtained, the next step is to calculate the electricity generation from the burning of biogas in an internal combustion engine. A simple model that suggests the calculus of potential electricity generation from landfill biogas is shown in Equation 2.

$$
P G=Q \cdot L H V \cdot \eta
$$

Equation 2

Where $P G$ is the power generation potential from landfill biogas per year $(G W h / y), Q$ is the total landfill biogas emission rate per year, also known as the volumetric flow of methane $\left(\mathrm{m}^{3} / y\right), L H V$ is on average $18.54 \mathrm{MJ} / \mathrm{m}^{3}$ representing the lower heating value of methane and $\eta$ is the conversion efficiency from biogas to electricity by a combustion engine generator, assumed to be $34 \%$ at $80 \%$ of the rated power, according to (Vargas Bautista \& Calvimontes, 2017). Table 2 summarizes the assumptions made for the variables used in gas emission rate and power generation per year.

Table 2. Parameters to evaluate the landfill biogas and power generation.

\begin{tabular}{cc}
\hline Parameter & Assumed value \\
\hline$L_{0}, \mathrm{~m}^{3} / \mathrm{Mg}$ & $100-180$ \\
$k, y^{-1}$ & 0,05 \\
Collection efficiency & $80 \%$ \\
Methane generation from biogas & $50 \%$ \\
Methane LHV (low heating value), $\mathrm{MJ} / \mathrm{m}^{3}$ & 18,54 \\
\hline
\end{tabular}

Source:(Vargas Bautista \& Calvimontes, 2017).

Equation 2 model was applied using data obtained for the Valencian region from the period 2013 to 2016 and the annual estimation of the USW in the three provinces to obtain the amount of electricity generation from biogas formula. Also, an electric generation projection is made with the annual cost of the energy generated.

\section{Results}

Results of applying the previously proposed biogas production and power generation models from Equation 1 and Equation 2 were obtained. It is noticed that the production of biogas from 2016 to 2026 remains invariable. While biogas production slowly decreases, new landfills should be created to cover the needs of trash disposal, preserving the production of biogas. Figure 2 shows the estimated biogas production for each of the provinces of the Valencian Region under the scenario raised. A landfill creation is proposed in Castellón by 2020, in Alicante for 2023 and in Valencia by 2025, according to the order of its useful term of life. Average annual production of 2,499 megagrams of biogas is estimated for the Valencia Region from 2020 to 2032. 
Figure 3 shows the estimate of power generation from landfill biogas from 2020 to 2032, as well as contributions to that power from each province of the Valencian Region. As is shown in Figure 3, if three landfills of at least the capacity of Onda, Dos Aguas and Alicante are opened before these are filled in the next 6 years, them from 2020 to 2032 there would be an average annual generation potential of $6,37 \mathrm{GWh} /$ year, (Average total demand in the Valencian Region is $22138 \mathrm{GWh} /$ year).

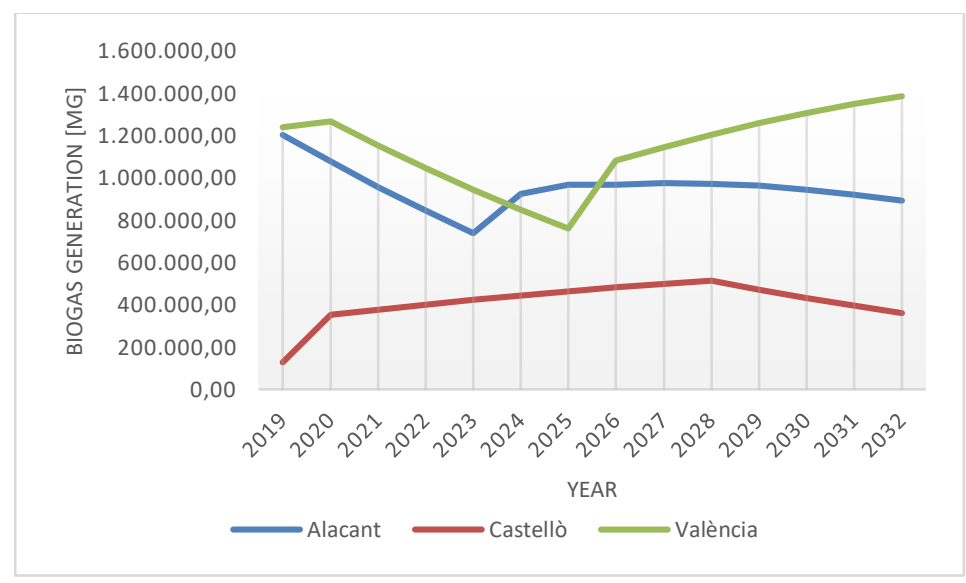

Figure 2 Annual electricity potential power generation from landfill biogas projections from the years 2020 to 2032.

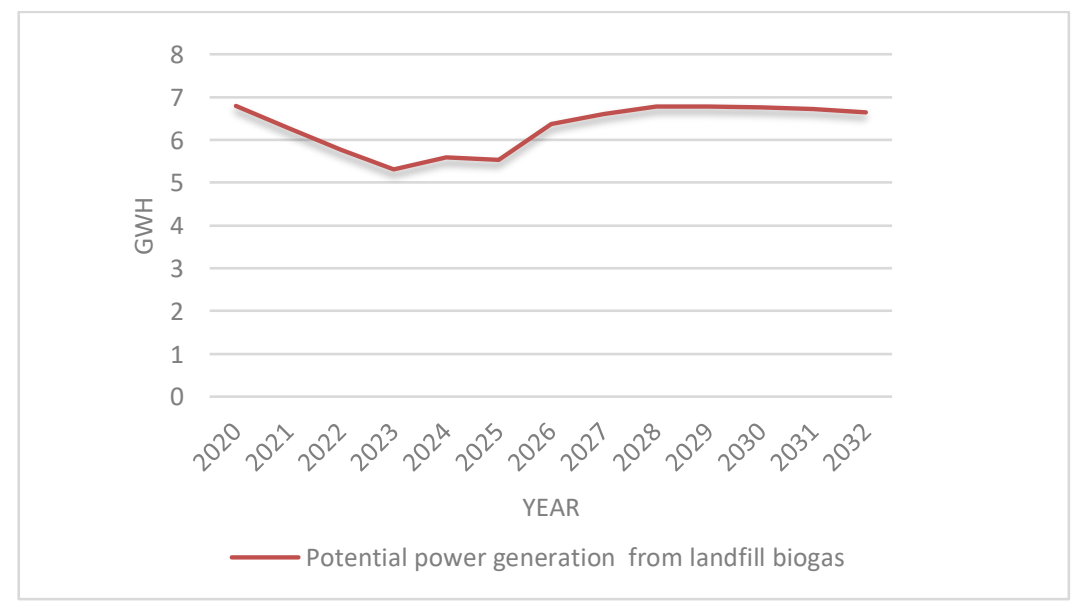

Figure 3 Annual electricity potential power generation from landfill - biogas projections from the year 2020 to 2032.

As of 2011, its inhabitants generated 5.9 tons of $\mathrm{CO}_{2}$ per capita per year in the Region of Valencia, ("Cada valenciano emite dos toneladas de $\mathrm{CO}_{2}$ menos que el conjunto de la media 
nacional"). Using data obtained from biogas production and power generation it can be estimated the number of equivalent tons of $\mathrm{CO}_{2}$ that could be saved by leveraging the biogas production for power generation. Figure 4 shows the possible contribution in carbon equivalent tons obtained from biogas generation against the total estimated carbon equivalent tons of the Valencian Region according to (Valencia Plaza, 2017). On average, according to the results shown in Figure 4, from 2020 to 2032, a reduction of $8 \%$ to the total of the equivalent carbon tons would be obtained.

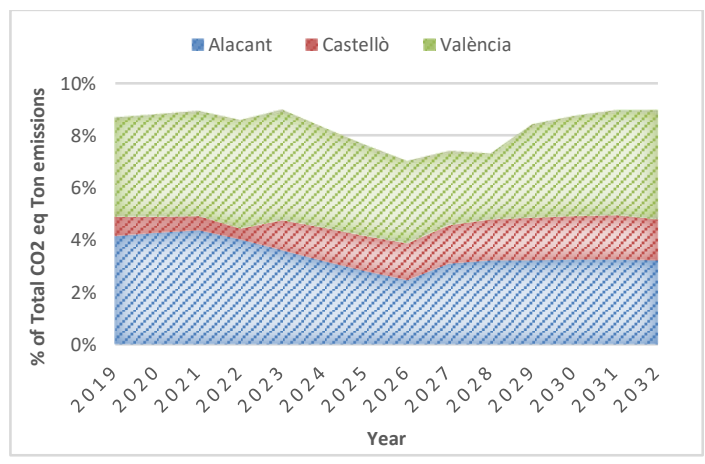

Figure 4 (a) Equivalent tons of carbon saving from biogas related to total equivalent tons of carbon of the Valencian Region.

\section{Discussion}

The results of this work show that while the percentage of estimated power generation from biogas under the scenario proposed is little compared to the estimated total energy demand of the Valencian Region, $6.5 \mathrm{GWh}$ /year vs. 21,965 GWh/year on average, for the next few years, that generation could result in a significant reduction in greenhouse gas emissions, as approximately $8 \%$ of the Valencian Region's total carbon-equivalent ton emissions could be used in power generation from biogas, rather than the use of other energy sources as fossil fuels.

\section{References}

Cada valenciano emite dos toneladas de $\mathrm{CO} 2$ menos que el conjunto de la media nacional. (n.d.). Retrieved June 27, 2019, from https://www.elperiodic.com/cada-valenciano-emite-toneladasmenos-conjunto-media-nacional_133099

Consellería de Infraestructuras, T. y M. A. (2013). Análisis y diagnóstico de los RSU de la Comunivad Valenciana. Plan Integral de Residuos de La Comunidad Valenciana, 149. Retrieved from http://www.citma.gva.es/documents/20549779/161513659/02.+Residuos+urbanos/57c112cf$563 \mathrm{~b}-4 \mathrm{c} 09-8 \mathrm{c} 2 \mathrm{a}-070 \mathrm{~b} 2 \mathrm{~d} 968 \mathrm{~d} 19$

Diversificación y Ahorro de Energía, I., Armengol, G., \& Farré, O. (2011). Situación y potencial de valorización energética directa de residuos. Estudio técnico PER 2011- 2020. Plan de Energías 
Renovables, España, 1-134.

Igliński, B., Buczkowski, R., \& Cichosz, M. (2015). Biogas production in Poland - Current state, potential and perspectives. Renewable and Sustainable Energy Reviews, 50(2015), 686-695. https://doi.org/10.1016/j.rser.2015.05.013

Infraestructuras Territorio y Medio Ambiente, C. (2012). Análisis de la situación y gestión de los residuos en la Comunitat Valenciana. Valencia.

Lima, R. M., Santos, A. H. M., Pereira, C. R. S., Flauzino, B. K., Pereira, A. C. O. S., Nogueira, F. J. H., \& Valverde, J. A. R. (2018). Spatially distributed potential of landfill biogas production and electric power generation in Brazil. Waste Management, 74, 323-334. https://doi.org/10.1016/j.wasman.2017.12.011

Nadaletti, W. C., Cremonez, P. A., De Souza, S. N. M., Bariccatti, R. A., Belli Filho, P., \& Secco, D. (2015). Potential use of landfill biogas in urban bus fleet in the Brazilian states: A review. Renewable and Sustainable Energy Reviews, 41, 277-283. https://doi.org/10.1016/j.rser.2014.08.052

Rios, M., \& Kaltschmitt, M. (2016). Electricity generation potential from biogas produced from organic waste in Mexico. Renewable and Sustainable Energy Reviews, 54, 384-395. https://doi.org/10.1016/j.rser.2015.10.033

Sanchís, J. (2019). Los principales vertederos de la Comunitat se saturarán en apenas seis años | Las Provincias. Retrieved June 27, 2019, from https://www.lasprovincias.es/comunitat/principalesvertederos-comunitat-20190109004944-ntvo.html

Valencia Plaza. (2017). Las empresas de la Comunitat Valenciana han emitido gases por valor de más de 42 millones de euros - Valencia Plaza. Retrieved June 27, 2019, from https://valenciaplaza.com/las-empresas-de-la-comunitat-valenciana-han-emitido-gases-porvalor-de-mas-de-42-millones-de-euros

Vargas Bautista, J. P., \& Calvimontes, J. (2017). Evaluation of Landfill Biogas Potential in Bolivia To Produce Electricity. Investigacion \& Desarrollo, 17(1), 55-62. https://doi.org/10.23881/idupbo.017.1-5i 